\title{
"A Stranger Arrives": The Art and Writing of Frederick Ost in New Zealand
}

"A Stranger Arrives", was the title of a large, detailed pen and ink drawing, dated 1944, made in New Zealand by Frederick Ost, and reproduced in a book of Ost's drawings titled Tikis: Impressions in Black and White, published in Wellington in 1946. Who was Ost? And why is there a paper on him in a symposium devoted to the life and work of Karl Wolfskehl in exile? Frederick Ost (1905-85) was a Prague-trained architect (who also had an engineering qualification), an artist and illustrator, a poet, playwright and essayist, and a translator and editor of other people's writings. He arrived in New Zealand in 1940 with his wife, Greta Ostova, a professional cellist, via Poland and England, as a refugee from Nazism. Ost is largely unknown and forgotten today, both as an artist and a writer, in New Zealand, as well as in Germany and the Czech Republic, even though he was quite widely published in German and Czech from the late 1920s - he is listed in German dictionaries of literature 1 - and in New Zealand in the early and mid 1940s, and even though his art was either exhibited or reproduced in books or periodicals in Czechoslovakia in the 1930s, New Zealand, particularly in the 1940s, possibly in Australia in the early 1970s, and in Austria in the early to mid 1980s.2

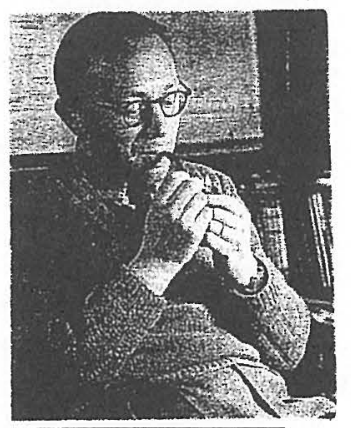

One wonders why his art and writing has largely disappeared from public consciousness, especially in New Zealand, the place he made his home. In a formal and aesthetic sense his work may be relatively minor. Yet the nature and variety of his activities as artist and writer, the diversity of his connections and the strategies he adopted to place his work in the public realm, given the circumstances of his displacement and exile in the 1930s and

1 E. g. Kürschners Deutscher Literatur-Kalender, Berlin 1984, p. 893; Kosch, Wilhelm (ed), Deutsches Literatur Lexikon, Vol II, Bern, Stuttgart 1968, pp. 744-45.

2 See Bell, Leonard, "A Series of Displacements: An Introduction to the Art of Frederick Ost," Art New Zealand, No. 86, Autumn 1998, pp. 64-68. 
1940s, have significances and resonances which make his work and career worthy of retrieval, investigation and review. Indeed his work and career can provide an exemplary, in the sense of paradigmatic, case study of the predicaments and problems faced by artists and writers, displaced from German-speaking or bi-lingual countries or cultural milieux to English-speaking countries in the 1930s and 1940 s, and of the tensions, dynamics and complexities of the resulting encounters between "foreigner" or "stranger" and nativeborn.

Ost had links with Wolfskehl in New Zealand. From 1943 to 1945 they corresponded in a friendly manner over several matters, though with one residing in Auckland, the other in Wellington, they never met. ${ }^{3}$ Ost undoubtedly knew of Wolfskehl's writing before coming to New Zealand. He initiated contact. Wolfskehl did not know of Ost's before this. In an early letter to Wolfskehl Ost listed his published writings in German and Czech and sent him some of his writings, both published in English - a long poem One Amongst Us, and a pictorial narrative, My Little Book of Swallows - and in German, both published, Dagmar-Lieder, and unpublished, "Jüdische Tragödie." Wolfskehl's responses to these works were diplomatic, though it seems he rated them as only minor on the literary scale. Ost appears to have been quite ambitious. His letters to Wolfskehl indicate that he had made contact with several major exile German-language publishers - for instance, the leftist El Libro Libré in Mexico City, as well as Schocken in Tel Aviv. Ost had sent his plays "Jüdische Tragödie" and "The Natoneks," also known as "The Czech Tragedy", to both publishers for consideration. 4 Ost's political affiliations or sympathies were with the Marxist left (without, to my knowledge, ever having been a member of the Communist Party), and this colouring is evident in his published writings of the 1940s. Given the apolitical nature of Wolfskehl's poetry and his belief in the need to keep the poetic and the political separate, it is possible that this fundamental difference between the two men may have affected their otherwise friendly relationship - to their relationship never developing beyond correspondence, to Ost remaining on the periphery of Wolfskehl's

3 For Wolfskehl and Ost's correspondence see BaN II, pp. 559-570. Further unpublished letters are held in Deutsches Literatur Achiv (DLA), Marbach.

4 Ost to Wolfskehl, 23. 9. 1943, BaN II, p. 559, Ost to Wolfskehl, 7. 12. 1943, DLA. Both "Jüdische Tragödie" and "The Natoneks" remained unpublished. El Libro Libré no longer exists. Schocken, Tel Aviv, have not retained unpublished manuscripts from the 1940s. 
concerns and world in exile. Another likely contributing factor to this relates to Wolfskehl's poem "Kalon Bekawod Namir". Ost, with the assistance of a New Zealander, "R. M." (Ronald Meek), translated it into English, and with Wolfskehl's approval, hoped to arrange publication of that translation. "with two illustrations." Wolfskehl, though, was reluctant to have the poem published in English. Neither was he satisfied with the various translations, and Ost's project came to nothing. 5

The remainder of this essay is going to focus almost entirely on Ost's work, or some of it, in New Zealand from 1941-46. To provide a summary background it might be useful, though, to note his pre-war German and Czech publications. From the 1920s Ost belonged to a group of German language writers in Czechoslovakia, the "Freie Gruppe Prag", which included H. G. Adler, Franz Baermann, Wolf Salus and Paul Leppin. ${ }^{6}$ His first book, Um ein wenig Liebe had been published in Radolfzell in 1929, then came his stories Milka, 1930-31, his ballads Asphalt 1931, stories Masken des Alltags and his play Zerstörte Jugend 1932, his plays Jack Hill and Alcohol and poems Dagmar-Lieder in 1935, all in Germany. A book of Ost's ballads, two plays and essays on Czech writers had also been published in Czech, while he had translated several works by 19 th and 20 th century Czech writers into German. ${ }^{7}$ There are no copies of those pre-war publications in New Zealand libraries, and none of Ost's friends in New Zealand or his relatives in England have copies. So, at present, there are gaps in my Ost archive, and the public holdings in New Zealand of his literary and artistic output remain partial and fragmentary.

What is readily evident, though, is the range and diversity of Ost's activities - remember he was also a painter and an architect - and

5 See Ost to Wolfskehl, 1. 10. 1943, 15. 10. 1943, BaN II, 14. 11. 1943 DLA, Wolfskehl to Ost, 7. 10. 1943, 19. 10. 1943, 30. 11. 1943, BaN II.

6 Atze, Marcel, "Ortlose Botschaften". Der Freundeskreis H. G. Adler, Elias Canetti und Franz Baermann im englischen Exil. (Marbacher Magazin 84/ 1998). Marbach 1998, pp. 13-14.

7 For instance, he had translated into German works by the Czech writers Jaroslav Vrchlicky (1853-1912), Karel Toman (1877-1946), Frantisek Salda (1867-1937) and Vitezslav Nezval (1900-58). See Ost to Wolfskehl, 1. 10. 1943 and Kürschners Deutscher Literatur-Kalender, p. 893. Ost's Czech publications included Pisne vsedniho and Asfalt (both Obzina), verse in Duch Casu (Ostrava) Youth (Prague) and Utok (Prague). His plays, The Saviour and The Execution of Jacob Hill, were broadcast by the Ostrava National Broadcasting Station. See biographical notes on Frederick Ost, 3 Essays on Czech Poets, Wellington 1944, and Frederick Ost and Ronald Meek, The Vltava Still Sings, Wellington 1946, p. 34. 
these continued after his arrival in New Zealand. He quickly made contact and worked with a variety of people and groups in the literary, artistic and academic mileux of Wellington - most notably with Noel Hoggard (1913-79), a then well-known poet, publisher, printer and editor, who ran The Handcraft Press, which produced about forty books of verse and essays, as well as three periodicals from the mid 1930s to the mid 1940s.8 I have noted that Ost worked with Ronald Meek (1917-78), a leading figure in the leftwing Unity Theatre, a critic, essayist and satirist who left New Zealand in 1946 for Great Britain on a PhD Scholarship and became an eminent historian of economic and political ideas and theory there. 9 Ost also knew Ian Gordon, Professor of English at Victoria University, and editor of the annual $\mathrm{New}$ Zealand $\mathrm{New}$ Writing, 1942-45. Professor Gordon, recommended that the Progressive Publishing Society publish a book of Ost's and Meek's (then a member of the Communist Party) translation of sixteen contemporary Czech Socialist poets, the Vltava Still Sings (1945) 10 which was printed and its cover designed by Caxton Press. Ost also wrote an introductory essay for this book, dedicated to "our Czech brother poets imprisoned in German concentration camps or fighting underground somewhere in Czechoslovakia."11 The Progressive Publishing Society had already published Ost's 3 Essays on Czech Poets (1944) and his translations of other Czech writers were also published by Hoggard's The Handcraft Press notably Frantisek Halas's long poem, Our Lady Bozena Nemcova

8 For Hoggard's The Handcraft Press, see, for instance, Grayland, Eugene Private Presses: Their contribution to Literature and Typography, Auckland, 1947, pp. 30-31, and McEldowney, Dennis, "Publishing, Patronage, Literary Magazines", in: The Oxford History of New Zealand Literature, (ed Terry Sturm), Auckland 1991, p. 585. See, too, Hoggard, Noel Farr, The Inky Way: An Essay into Autobiography, Wellington 1940, and his essay, "Forgotten Men Whither the Refugee", New Triad, May-June 1939, in which he made a plea for more humanitarian response to refugees from Nazism: "Our immigration laws are unnecessarily harsh...", p. 18.

9 For Meek's British career see Bradley, Ian and Howard, Michael (eds), Classical and Marxian Political Economy: Essays in Honour of Ronald L. Meek, London 1982. For Meek's theatre activities in New Zealand and involvement with the Progressive Publishing Society see Barrowman, Rachel, A Popular Vision: The Arts and the Left in New Zealand 1930-1950, Wellington 1991, especially Ch. 6, "Left Theatre."

10 Thanks to Professor Gordon for advice. The Vltava Still Sings includes an acknowledgement "To Professor I. A. Gordon, for friendly advice and assistance".

11 The Vltava Still Sings, p. [2]. 
(1945) and Frana Richter's story "Holiday", in the periodical, Arena, in 1946. Earlier Hoggard had published Ost's long antiFascist ballad, One Amongst Us (1944), with an expressionistic wood engraving by Ost as the frontispiece illustration. Other collaborations of Ost and Hoggard included Ost providing illustrations for a book of Hoggard's own poems, The Moon's Face is Wrinkled (1944)12, and their co-editing of an anthology of poems about, or inspired, by the war, Poems from Allied Nations (1944). This featured work by twenty-five poets (including Ost) from thirteen nations. Mao Tse Tung makes a brief appearance. ${ }^{13}$

This book, too, can be seen as evidence of the range of Ost's connections and contacts outside New Zealand - unusually varied for someone writing in New Zealand then and rarely found among New Zealand-born writers. Ost also wrote book reviews for Hoggard's periodical Letters - for instance of the New York edition of the exiled German poet Walter Mehring's No Road Back (1945), and of New Zealand New Writing No 4 - while his drawings and linocuts were reproduced, full page, in the periodicals, Letters and Arena. 14

These modernist images, whether Cubist, Constructivist or Expressionist in style, were unusual in, and new to, New Zealand visual culture in the early 1940 s - a visual culture that was predominantly, allowing for some exceptions, conservative and British-oriented, even anti-modernist in practice and attitude.15 Ost's first publication in New Zealand (1941) had been his pictorial narrative My Little Book of Swallows, comprising twenty drawings, with brief captions, in a style that brings to mind some German Bauhaus connected artists, 16 while his first piece of writing in English, the allegorical piece, "Jesus in Maoriland", had appeared with illustrations in New Zealand's only art periodical, Art in New Zealand in 1941. His second book of published drawings, Tikis:

12 Ost's linocuts were characterised as "intriguing" in The Dominion, quoted in Letters, June 1944.

13 The New Zealand poets included were Charles Brasch, Anton Vogt and Paula Hanger.

14 Ost's artworks were reproduced in the No 4, March and No 5 June issues 1944 and the No 8, April 1945 issue of Letters and in Arena in December 1946 and July 1947.

15 See Bell, op. cit. See, too, Pound, Francis, The Space Between. Pakeha Use of Maori Motifs in Modernist New Zealand Art, Auckland 1994.

16 See Bell, op. cit. My Little Book of Swallows was reviewed in Art in New Zealand, Vol XIV, .No. 1, September 1941, p. 44: "It has an originality, particularly in the pictures". 
Impressions in Black and White, comprising seven images plus a cover image, as noted, was published by The Handcraft Press in 1946. "Tiki in Mirror" and the cubist "Still Life" are from that book.

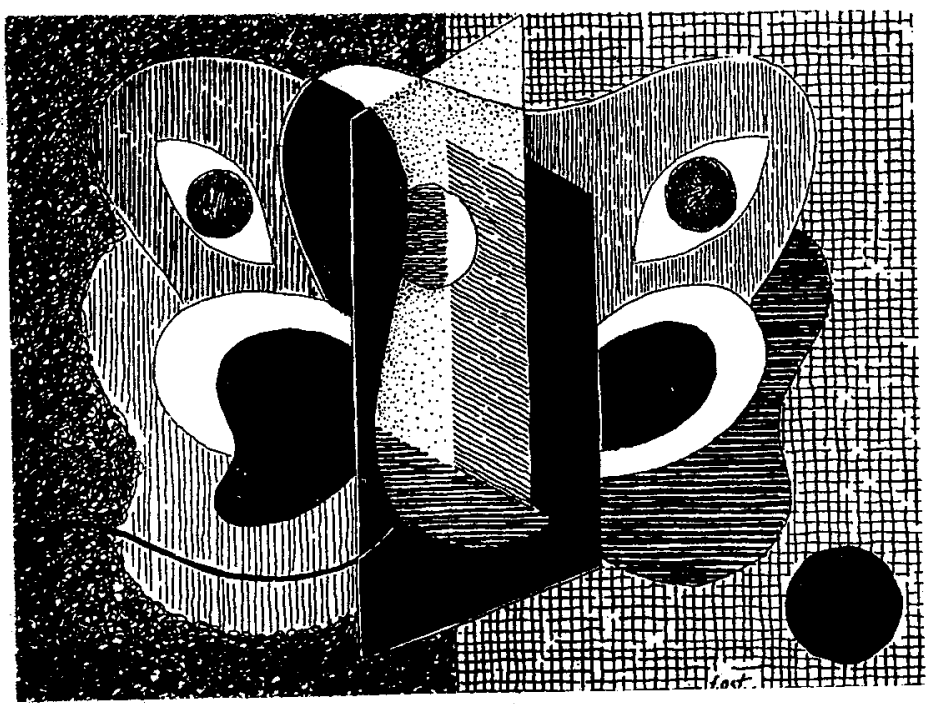

Frederick Ost, Tiki in Mirror (1946)

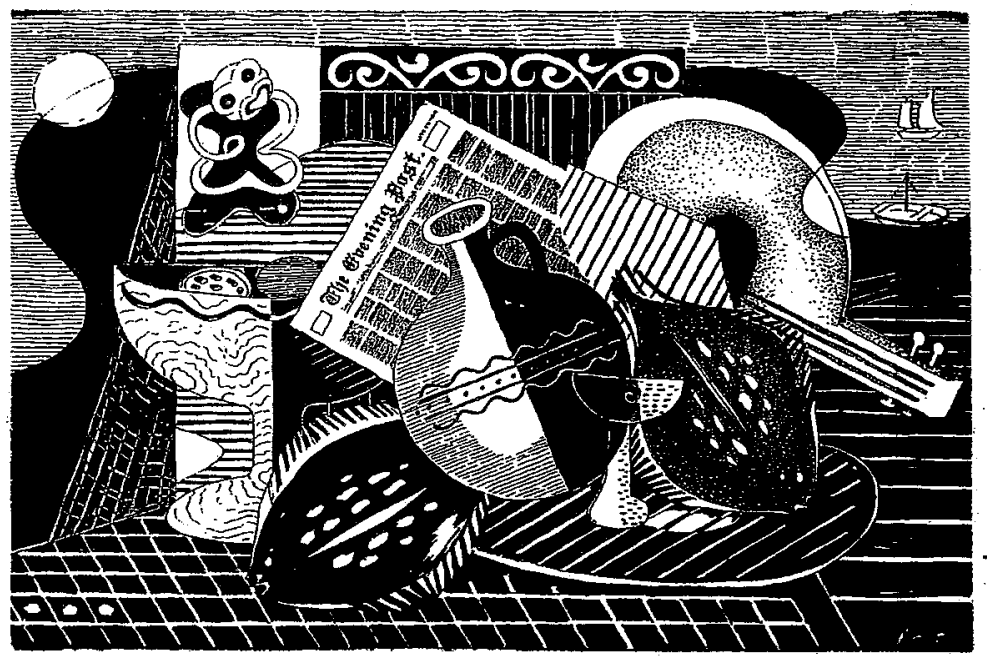

Frederick Ost, Still Life (1945) 
These two images can be seen to mark simultaneously Ost's difference as a newcomer in New Zealand, insofar as Cubism was little-known, generally regarded as "alien" to New Zealand's visual culture, and his attempt to orient himself to being in New Zealand, to relate to the place to which he had come. Thus there are the distinctively New Zealand elements or referents - the figure in "Tiki in Mirror" referring to the carved tiki figure of Maori art, and in "Still Life", besides a tiki, the wave or scroll-like motif referring to kowhaiwhai, Maori rafter painting. I should note that in the mid 1940s in New Zealand it was almost unprecedented for a European or Pakeha artist to combine the modernist and Maori referents.

I have given the "bare facts" of Ost's publicly-seen art and writing in New Zealand in the early to mid 1940s. So, as a new arrival in a country with a small population - about two million - and, by European standards, artistic and literary milieux with only rudimentary institutional support structures and relatively few fulltime or professional artists and writers or outlets for the exhibition or publication of modernist-informed works, Ost quickly attempted to enter into and participate in those milieux - though, as it turned out, with mixed responses from the locals and with virtually no lasting impact.

So where does Ost's "A Stranger Arrives" fit in? This image can be seen to embody or encapsulate fundamental aspects of a sociocultural moment that had immediately personal and also generic reverberations - the new configurations or "spaces" created by, or opened up by, the arrival of Central European, largely Jewish and German-speaking or multi-lingual middle-class, highly cultured professionals as refugees from Nazism in places very different, linguistically, culturally, ethnically; in places where these refugees were generally regarded as alien; "strangers".

"A Stranger Arrives" is a complex pictorial construction, - in which a plurality of elements - figural, landscape, still life - thematic references, and formal or stylistic devices or features - Cubist, Constructivist, Expressionist, more conventionally, diagrammatically figurative and Maori art-inspired or derived - were brought together in the one image. These elements, references, and devices immediately might seem incompatible, at odds with one another. In particular, complicating the image, was Ost's use of the compositional device of the picture within the picture. " 


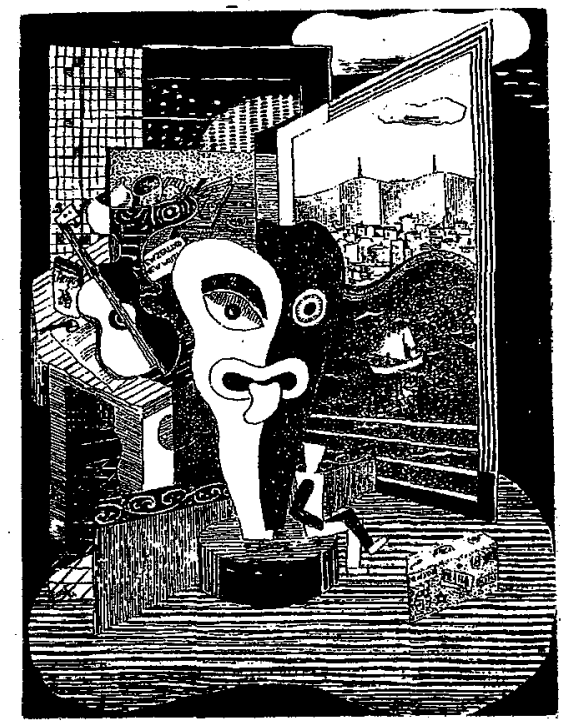

Frederick Ost, A Stranger Arrives (1944)

A Stranger Arrives" is composed of several intersecting or overlapping pictures. Central to the image overall are the black and white, statue-like frontal tiki figure and, easy to overlook, at its base a small seated profile figure, also black and white - a kind of mannekin, a small reduced human. To the right of these there is an internally-framed land or harbourscape - the site of arrival. To the left there are two more internally framed pictures, or rather parts of pictures - one, insofar as one can see it, in an abstract, Constructivist mode, the other a Cubist still life. Elements of this; notably the guitar and part of the vase, appear to have slipped out of their frame into the main picture. The suitcase on the lower right with its labels - New York, Praha, Lisbon, Paris - could also be seen as a picture within the overall picture. These pictures, or parts of pictures, abut one another obliquely; their boundaries can be unclear or broken. As such they constitute a series of spatial dislocations which combine into an overall image that is split or fractured in various ways, rather than being organised in terms of a homogeneous, united, coherent interrelationship of parts to a whole.

This formal structuring has socio-cultural, and perhaps psychological co-relatives, even if the picture resists a simple or singular 
explanation or decoding of its heterogeneous parts. It is full of clues, cues and references to a diversity of places and experiences. Elements from a variety of worlds, geographic, cultural, artistic, near and far, are brought together around those paired central figures - the tiki and "the little man". The latter, perhaps, represents that stranger, unidentified, unidentifiable, who has arrived - Ost himself and the "everyman" refugee, the refugee diminished by his circumstances, facing the need to rebuild? Personal references are included in the picture - for instance, the musical instrument, while on one hand, a staple ingredient of the Cubist iconographic repertoire, could connote his wife's profession, while the pipe and tobacco tin, also part of the Cubist repertoire, could be linked to Ost's own avid pipe-smoking. The words $\mathrm{New}$ Zealand New Writing might seem an anomalous inclusion, but its editor, Ian Gordon, assisted Ost to publish in New Zealand. The harbourscape, with its relationship of buildings, hills and radiomasts is identifiably, even if diagrammatically, Wellington, where Ost settled. The label "Praha" on the suitcase refers to the Czechoslovakia from where Ost had come, though, in fact he was living in the industrial city of Ostrava, probably unheard of in New Zealand, before his escape. The suitcase with its labels could, of course, in itself stand for more than just movement from one place to another, but to the displaced person's, the person in flight, ever-present suitcase - emblematic of the need to be always ready to leave, to go some place else.

The arriving stranger, then, is, or has been in a labile or unstable state, liable to sudden change, in-between two or more places or worlds, neither just here nor there. This stranger, though, as represented by Ost, was one who was attempting to engage with the new place to which he had come, to become a member of that society, or groups within that society, rather than remaining on the outside - while at the same time bringing with him into that society, habits and practices from the home he had left. Thus, then, that central tiki figure and the kowhaiwhai pattern standing for the notEuropean, the distinctively New Zealand, the new place. Thus, the words 'New Zealand New Writing' referring punningly to Ost's writing and publishing in English. His writing was "new" in New Zealand. Thus, the stylistic and formal vocabulary derived from European modernism - Cubist, Constructivist - hitherto, largely alien, little-known, unused in New Zealand visual culture. There is, then, an interchange of elements stylistically, spatially, and in terms 
of identity or identification.

If it seems that I am constructing a thematic for Ost's picture that might seem overambitious for a work by a minor artist, note that work by a "minor" artist can be complex, as complex as work by a "major" artist. And consider, first, Ost's use of the device of pictures within the picture, and, second, the words of the title, "A Stranger Arrives", and bear in mind that Ost was widely read and well-informed on artistic and cultural matters, described by his friends as a sophisticated European intellectual.

On the right, there is the image of Wellington, to which the stranger has come. "Real space", that is, is pointedly rendered as part of a constructed set, as are the Cubism and Constructivism, or pastiches of those, of the juxtaposed pictures within the picture - the Cubist and Constructivist representing the space of the "foreign", Europe. Significantly the Constructivist picture, which is similar to Ost's Czech abstract studies of the early to mid 1930s, is obscured, partially hidden, indicating its "strangeness" to, or in, New Zealand visual culture then. These pictures of "here" and "there" provide the backdrop to the event of arrival, and suggest strongly that Ost was self-consciously, knowingly, staging a position, a set of relationships.

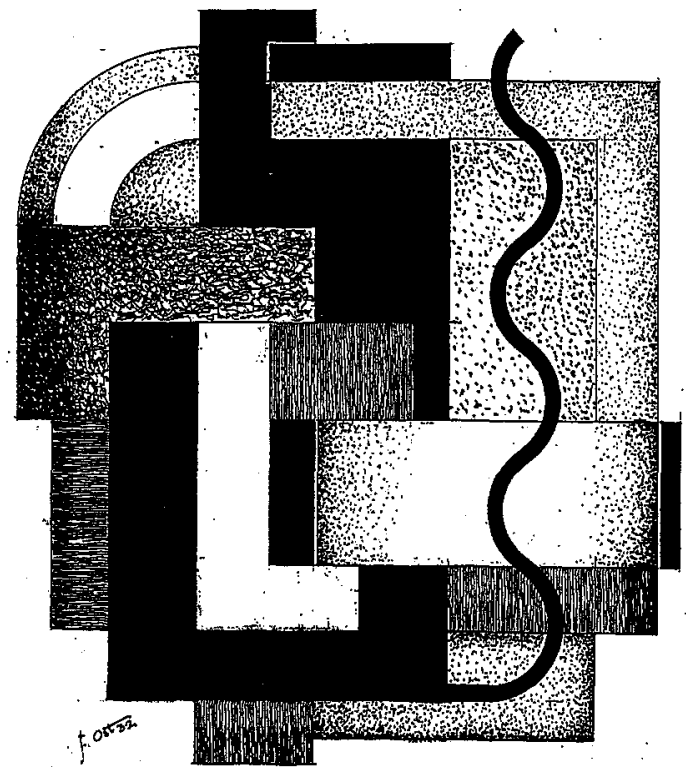

Frederick Ost, Untitled pen and ink drawing (1932) 
The title, "A Stranger Arrives", in itself suggests too Ost's awareness and exploration of the structural relationship of the stranger figure and the places or spaces, both socio-cultural and geographical, to which he came - the relationships of he who comes from outside to those inside. More particularly the title, brings to mind the formulations of a couple of earlier and mid-20th century German-speaking scholars, a brief consideration of which may help elucidate and bolster the connotations of Ost's image, irrespective of whether Ost knew of the particular texts.

The well-known in central Europe, widely-influential late nineteenth - early twentieth century German-Jewish sociologist George Simmel (1858-1918) in his essay, "The Stranger", characterised the stranger as a figure in which movement or wandering and fixity or cessation of movement were united: "the person who comes today and stays tomorrow"; one in whom nearness and distance were synthesised.17 The later Central European refugees to Englishspeaking countries typified those relationships. And more particularly, the artists and writers amongst them frequently and generally, and specifically in the case of Ost, epitomised the position in the social space to which they and he came that Simmel accorded his stranger (not that Simmel had been predicting this later phenomenon). Interestingly the 1950 American edition of Simmel's writings, which includes "The Stranger", translated, edited and introduced by Kurt $\mathrm{H}$. Wolff (another refugee from Nazism) was dedicated to Karl Wolfskehl.18 Simmel argued that the stranger was fixed within a particular, and new-to-him, social space, but that it was a position in the social space that was "determined by the fact that he has not belonged to it from the beginning, that he imports qualities into it which do not and cannot stem from the group -itself. ${ }^{19}$ Thus the Cubist, Constructivist and Expressionist elements in Ost's art and illustration, and thus his writing in English on Czech poets and translations of Czech poetry in New Zealand, where such work was unknown.

17 The Sociology of George Simmel (Translated, edited, with an Introduction by Kurt H. Wolff), Illinois 1950 , pp. 402, 404. Simmel's essay was first published in Simmel, Georg, Soziologie, Untersuchungen über die Formen der Vergesellschaftung, Leipzig 1908.

18 Ibid., Frontispiece Dedication to Hans Schiebelhuth and Oscar Louis Wolff, as well as Karl Wolfskehl.

19 Ibid., p. 402. 
Simmel, writing in the early 20th century, before the mass refugee phenomenon soon to come in Europe, characterised the position of his stranger positively, optimistically. In contrast, in another essay also titled "The Stranger", by the Austrian-Jewish scholar Alfred Schutz (1899-1959), written in very different circumstances, the figure of the stranger was characterised much less positively, even pessimistically as a social type in a much more vulnerable, less predictable relationship to the social space to which he had come; freighted with anxiety. 20 Schutz's "The Stranger" was written and published in the USA in 1944, to where he had come as a refugee from Nazism. ${ }^{21}$ Schutz's concern was "the typical situation in which a stranger [whether immigrant or refugee] finds himself in his attempt to interpret the cultural pattern of [the] social group he approaches and to orient himself within it" in an attempt "to be permanently accepted or at least tolerated by the group he approaches". 22 Schutz explored the strategies supposedly and typically adopted by newcomers, people from outside a particular society or social group, in attempts to become members of the group, to stay inside. Frequently, even invariably, Schutz argued, this stranger tended to interpret or represent his new social environment in terms of his "thinking-as-usual" - that is, in terms of the practices and concepts derived from the environment he had left - practices and concepts which may have had limited applicability in the new social environment, and limited acceptance from the indigenous members of the new environment. ${ }^{23}$ Prime aspects of Ost's art and writing in the early to mid 1940s in New Zealand could be used to exemplify such formulations of Schutz. Unwittingly on Ost's part it could almost be as if Ost were putting Schutz's formulations into practice. Indeed you could see "A Stranger Arrives" as an announcement

20 Wolff, Janet "The Female Stranger: Marginality and Modes of Writing", in her Resident Alien: Feminist Cultural Criticism, Cambridge 1995, p. 5, notes "Alfred Schutz's stranger [...] seems weighted down by anxiety, as he tries to fathom the taken-for-granted knowledge of the group he has joined."

21 Schutz's "The Stranger: An Essay in Social Psychology" was first read before the General Seminar of the Graduate Faculty of the New School for Social Research and first published in The American Journal of Sociology", Vol XLIX, No. 6, May 1944, pp. 499-507. For Schutz see Wagner, Helmut R., Alfred Schutz: An Intellectual Biography, Chicago and London, 1983, and Coser, Lewis A., "Alfred Schutz (1899-1959): Fountainhead of Phenomenological Sociology", in: Coser, Refugee Scholars in America: Their Impact and Experiences, New Haven and London 1984, pp. 121-25.

22 Schutz, Alfred, "The Stranger: An Essay in Social Psychology", in his

Collected Papers II: Studies in Social Theory, The Hague 1971, p. 91.

23 Ibid., pp. 96-9. 
of the arrival of Schutz's stranger - bringing into New Zealand's visual culture, his, Ost's, "thinking-as-usual" in terms of art practice, while at the same time, attempting to orient himself to being here, to gain a foothold. So the central tiki figure in the image and the series to which it belongs, Tikis: Impressions in Black and White. The result is what you have imaged were features or fragments from what were then, the mid 1940s, culturally divergent worlds - Central European modernist and New Zealand - located within the same space, though not unified within it - uncomfortable even; conjoined but disjunctive.

Schutz argued that the degree to which the "stranger" and the native-born or "in-group" could adjust to one another and absorb elements of the other's cultural pattern determined whether the stranger found acceptance, and thus ceased to be a stranger, or whether he remained a "marginal man", a "cultural hybrid on the edges of two differing cultural patterns, without really belonging to either".24 It is worth considering several of Ost's texts in English in relation to this formulation - texts which manifest pulls in two, possibly incompatible directions, and which, in retrospect, can be seen to point to Ost's marginality in the New Zealand literary world. On one hand, the fact that Ost chose to write in English and managed to get such writings published in New Zealand indicate a bid for acceptance, for a place in the literary world here. On the other hand, these writings are, hardly surprisingly in the circumstances, sustained by Ost's "thinking-as-usual" - that is, by the ideological and conceptual baggage of the Central European cultural, or sub-cultural milieu, from which he had come. This was a cultural pattern which New Zealand-born literati, with some exceptions, did not have much understanding of, and were not necessarily receptive to.

To elaborate of necessity summarily, and noting that I am extracting just some features or aspects of some of Ost's New Zealand writing, without reducing all his writings in their variety poems, plays, stories, essays - to just these features. Ost's two book reviews in the periodical Letters both manifest what now reads like a rather doctrinaire, even vulgarly Marxist view of the allegedly necessary marriage of the political and literature. In his April 1945 review of Mehring's No Road Back, while otherwise focusing passionately on the trials of Central European refugees and their often appalling treatment in France both before and after the

24 Ibid., p. 104. 
outbreak of war, Ost offered these views of that interwar European poetry and art, "that portrayed society in decay": He wrote that "the new brotherhood with the powerful rising proletariat strongly influenced Europe's art", with the poet or artist of note becoming "an accuser of social injustice and a fighter for a just and right future."25 More cogently to his New Zealand location, Ost in his July 1945 review of New Zealand New Writing No 4 negatively criticised the writing of most of the contributors as "petty-bourgeois" (while exempting the editor, Ian Gordon, from fault for this). Ost claimed there were no writers in New Zealand "able and willing to interpret today's gigantic struggle": "I maintain that the freezing worker, the miner, the wharfie, the munitions worker, the conductress, the labourer and the farmhand who helped shape New Zealand as she is today are objects worthy of being treated in artistic presentations [...] The psychological and social complex of New Zealand today is still waiting for its honest and true poet". 26 While Ost was not alone in criticising New Zealand New Writing from a Marxist position, 27 his views would not have been likely to have much support in the New Zealand literary milieu, in which most of the leading and emerging writers and publishers did not share such views.28 One could compare what could be characterised as Ost's misreading of the "cultural pattern" of the group from which he sought acceptance to the strategy that Ernst Toller, also otherwise Marxist-oriented, adopted as a refugee from Germany in England in his public lectures there in the mid to late 1930s. Toller downplayed Marxist analysis. Recent commentators have noted: "audiences of British writers were unlikely to be impressed by Marxist argument derived from a different cultural context."29

Ost's major literary works published in New Zealand, his three books of essays on and translations of Czech poetry, present a more complex phenomenon in terms of the dynamics of the relationships

25 Ost, Frederick, "Walter Mehring, No Road Back", Letters, No. 8, April 1945, pp. 12.

26 Ost, Frederick, "New Zealand New Writing No 4", Letters, No 9. July 1945, pp. 12-13.

27 See Barrowman, Ch. 5 "The Progressive Publishing Society".

28 Note there were some important literary figures, such as R. A. K. Mason and Arthur Sewell, who were Marxist.

29 Dove, Richard and Lamb, Stephen, "A Rebel in England? Ernst Toller's Campaign against National Socialism", in: Between Two Languages: Germanspeaking Exiles in Great Britain (London Research Group for German Exile Studies), Stuttgart 1995, p. 23. 
in the literary realm here between refugee/stranger and the Englishspeaking, New Zealand born. In the first of these books, 3 Essays on Czech Poets (1944), Ost described the works of Vrchlicky (1853-1912), Salda (1867-1937) and Bezruc (b. 1867, then still alive), all famous and celebrated in. Czechoslovakia, though unknown in New Zealand. Ost characterised them as representative of successive generations - a lineage - of writers driven by nationalist, democratic and egalitarian ideals, in relation to which he, Ost, voiced the Utopian Marxist belief in the need for an "active programme of solidarity" between "the progressive intelligentsia and proletariat of the whole world" in order to realise the "ideals of liberty, equality and fraternity." 30 It needs to be noted, though, that the primary thrust of this book was an assertion of Czech identity and spirit, and the role of writers in this in the past and present, at a time when Czechoslovakia was subject to Nazi barbarism, mass murder, and the "burning of their books." 31

A belief in the importance of the book in Czech culture and history, not just in articulating national identity, but in sustaining identity, language and culture in times of oppression, the importance of books and writing in Czech culture and history as acts of resistance and endurance, impelled also Ost's and Meek's translations of sixteen contemporary Czech poets, The Vltava Still Sings (1945)32 and his translation of the contemporary poet Frantisek Halas's Our Lady Bozena Nemcova (1945). For both books Ost wrote introductory essays, in which his internationalist socialist sympathies are evident. Halas's nine poems, described as poems of "faith and hope" "in dark days", 33 were first published in Nazioccupied Czechoslovakia in 1940; a publication that in itself was an act of resistance. These poems were dedicated to the mid-nineteenth century Czech woman writer, Bozena Nemcova (b. 1820),

30 Ost, Frederick, 3 Essays on Czech Poets, p. 22.

31 Ibid., p. 9. The first essay in 3 Essays on Czech Poets, "Lessing and Vrchlicky", was first given as a lecture in London on 13 February 1940 at the Friends House for the International Student Club. 3 Essays on Czech Poets, p. 8, includes a letter of acknowledgement of this essay from Dr Edward Benes, President of the Czechoslovak Republic in exile in London.

32 See "Czech Poetry. An Introduction by Frederick Ost", in: The Vltava Still Sings, pp. 5-11. Ost also provided biographical notes of the sixteen poets and annotations to some of the poems. The book includes "A Note for English Readers", pp. 12-14, by Ronald Meek.

33 Tigrid, Pavel, "Foreword" in Halas, Frantisek, Our Lady Bozena Nemcova, Wellington 1945. The book includes, too, a three page introductory essay on Halas and Nemcova by Ost. 
celebrated as a nationalist and republican writer in the days of Austrian imperium, and as "a symbol of the glory and suffering of the [Czech] nation." 34

These books of Ost's, with their concern with the special role of literature in expressing and preserving national and cultural identity among Czech peoples over the centuries, met with mixed responses in a New Zealand, in which the printed book, literature, simply did not have such a central place and function in culture and history, and in which such a status and role would probably not have been recognised or understood by most of the reading public. Indeed that may be a prime reason why Ost's two books on Czech poetry published by the Progressive Publishing Society were characterised by a member of that society as the kind of "serious, dull, academic-looking books [...] which were most difficult to sell."35 I have, to date, located very few reviews of Ost's books. There were a couple of positive and empathetic ones. ${ }^{36}$ However the only review in what in the mid 1940 s was the most widely distributed and read periodical featuring book reviews, The New Zealand Listener, was negative. Written by a J. C. B., in fact the Wellington-based prominent historian and leading, and powerful, cultural commentator, Professor J. C. Beaglehole, it is worth quoting in its entirety for what it hints at as much as for what it explicitly says:

"Mr Ost's Three Essays has a very nice cover. [Caxton Press designed]. As we know nothing about Czech poets in this country these outline accounts [...] have their interest - the interest of subject matter. Beyond that I cannot conscientiously go. The English language is difficult to write [...] and Mr Ost or the P.P.S [...] would have been wise to have got someone to knock it into shape [...] I'm sorry". ${ }^{37}$

While Ost's English was awkward, the review's emphasis on this, its

34 Tigrid, ibid.

35 Rachel Barrowman, citing Eileen Coyle of Progressive Books, p. 168.

36 Notably, an unsigned review of The Vltava Still Sings in Letters, No 9, July 1945, p. 18, and a review signed F. L. C. of 3 Essays on Czech Poets in National Education: The Journal of the New Zealand Educational Institute, Vol xxvii, no 287, 1 March 1945, p. 51.

37 J. C. B., "3 Essays on Czech Poets, by Frederick Ost", New Zealand Listener, 8 June 1945, p. 17. Ost wrote to Hoggard, 12 June 1945: "Beaglehole had a good kick when reviewing New Zealand poetry and my essays. I wonder what poor Professor Gordon said when he read Beaglehole's reactions", Noel Farr Hoggard Papers, MS 75-184, Alexander Turnbull Library, Wellington. 
dismissive tone and facetious touches, its very brevity suggests some unstated animus behind J. C B's comments. Could it have been in opposition to Ost's political views, that of the social democrat or liberal labourist to Marxism? Perhaps Ost's Marxism loomed larger in the minds of his readers than it warranted. J. C. B.'s comments also reveal a lack of any real interest in Czech poetry or empathy with Ost's concerns. Note the probably inadvertent echo of "as we know nothing about Czech poets" with Neville Chamberlain's dismissal of Czechoslovakia as a small country about which "we" know nothing, after the British and French betrayal of Czechoslovakia in Munich in 1938. This "stranger", Ost, it would seem, was not particularly welcome to this reviewer, J. C B. If that was so, J. C. B's response may well have been typical of New Zealand readers of poetry in the early to mid 1940s. In this respect note a comment about the Progressive Publishing Society in an essay titled "Publishing, patronage and literary magazines" in the recent Oxford History of New Zealand Literature: "A number of odd market decisions were made. What market was envisaged for Three Essays on Czech Poets by Frederick Ost?"38

Could these evaluations and assessments provide a reason or explanation as to why Ost stopped writing for publication in New Zealand, why he was silent in English after 1945, why his later publications were in German. Obviously it would have been difficult for any mature German-language poet, novelist or dramatist to adopt and write successfully in a second or third language, English, and relatively few refugee writers managed this transition anywhere - Great Britain or USA.39 I suspect, though, that Ost's unsuccessful attempt to become a writer in English in New Zealand was not just the result of an alleged insufficient linguistic facility. Much of his published writing in English made few, if any concessions to the prevailing tastes, attitudes and beliefs of New Zealand-born literati

38 McEldowney, Dennis, "Publishing, Patronage, Literary magazines", The Oxford History of New Zealand Literature in English, Auckland 1991, p. 594.

For a later example of a rather ungenerous and misconceived assessment of aspects of Wolfskehl's writing, in particular his letters, in New Zealand, see Carter, T. E., "Zehn Jahre Exil Briefe aus Neuseeland, 1938-48. Karl Wolfskehl. Edited by Margot Ruben". Landfall, 55, Vol. 14, No. 3, September 1960, pp. 293-5.

39 In respect of this, see, for instance, Coser, and Heilbut, Anthony Exiled in Paradise: German Refugee Artists and Intellectuals in America from the 1930s to the Present, New York 1983, and Dove, Richard, "The Gift of Tongues: German-speaking Novelists writing in English", in: Between Two Languages: German-speaking exiles in Great Britain 1933-45, pp. 95-116. 
and readers. In the social space of literature in New Zealand in the 1940s "stranger" and New Zealand-born do not appear to have adjusted to one another and accepted and absorbed elements of the other's "cultural pattern".

Perhaps the "personal reactions" of the expatriate British writer, Anna Kavan, in New Zealand during 1941-42, and herself a kind of exile, have some relevance here. Kavan (not coincidentally a Czech-sounding name; a Kafka-inspired pseudonym she adopted) wrote in 1943 in Horizon, the British periodical edited by Cyril Connolly and read by Wolfskehl:

"I don't like the defensive attitudes towards newcomers [in New Zealand], the old insular 'here comes a stranger, let's throw a brick at him' attitude. What happens when a stranger enters what's called intellectual circles? Do the sturdy colonials care if Einstein or the Cham of Tartary is in their midst? Brother, they do not care, they do not wish to hear from you, and unless you can speak louder than they can you're as good as dumb [...] [their] minds are closed against strangers". 40

While Ost did have support from some New Zealand writers and academics - notably Hoggard, Meek and Professor Gordon, as I have noted - one senses from the vehemence of his remarks about New Zealand writing generally in a letter to Wolfskehl a kindred feeling of marginality, if not so extreme as Kavan's sense of complete exclusion. "On the topic of New Zealand writing", Ost wrote, "I do not think contact with these people has a stimulating influence; the repugnant arrogance with which they imitate the big English brother and the hard-working American nephew results in a situation where nothing natural can emerge [...] We will never be able to create a community here, let along a group of followers." 41

40 Kavan, Anna, "New Zealand: Answer to an Inquiry", Horizon, Vol. VIII, No. 45, September 1943, pp. 160, 162. Thanks to Francis Pound for this reference. Anna Kavan, a. k. a. Helen Ferguson or Edmonds, adopted the Kafka-inspired pseudonym c. 1939-40. See Callard, D. A., The Case of Anna Kavan: A Biography, London 1992. Kavan was characterised as "displaced and alien" in New Zealand by Kendrick Smithyman in his Introduction to Greville Texidor's In Fifteen Minutes You Can Say a Lot, Wellington, 1987, p. 12.

41 Ost to Wolfskehl, 15. 10. 1943, BaN II, S. 564: "Zum thema N.Z. schriftum ist wohl einiges zu sagen: ich glaube nicht, daß der kontakt mit diesen leuten befruchtend wirkt; die widerliche arroganz, mit der der große englische bruder and der tüchtige amerikanische neffe nachgeahmt werden, bringt es mit sich, daß nichts urwüchsiges entstehen kann [...] Wir werden hier niemals eine gemein- 
To put it bluntly, having been active and quite widely visible in the early to mid 1940s, Ost did not establish a place in New Zealand's literary world. He dropped out of sight. The same applies to his forays into New Zealand's art world. Though he is believed to have had a couple of exhibitions in the early 1960s and 1970s and to have sold his paintings and drawings, he did not become a "player" in modernist-informed New Zealand art, as it emerged and developed in the 1950s and more particularly in the 1960s and 1970s. With the exception of an article of mine Ost is simply absent from New Zealand art historical writing, unknown, his work publicly unseen. ${ }^{42}$

Having been uprooted from his original home or homes Czechoslovakia and Central European German-speaking cultural life - where he had been active as an artist and writer, Ost did not get past being a stranger to, or in, the literary and art worlds of New Zealand. Yet he chose to remain in New Zealand and he regarded New Zealand otherwise as his home. $43 \mathrm{He}$ continued with his art and writing, though his later books, public outlets for both his drawings and poetry, were published by a small, now defunct press in Austria, J. G. Bläschke. ${ }^{44} \mathrm{He}$ was both here and elsewhere. He continued to be pulled in differing directions. Perhaps the images of fractured faces that were included in his last volume of poems, Zeitgenossen im Zerbrochenen Spiegel (1985), visualise a sense of a subject split in various ways - between two or more languages and cultural patterns, for example - a not uncommon state of consciousness or sense of being among refugees from central Europe.

\footnotetext{
schaft geschweige denn eine gefolgschaft aufbauen können.”. Interestingly, in Kavan's opinion, "sturdy Colonial independence [...] too independent to display any interest in anyone from outside [...] means everything (to New Zealanders) because, precisely, they haven't got it, they're still tied up to the home they call 'England, they've never cut the umbilical cord." Kavan, op. cit., pp. 160-161.

42 There are no paintings or drawings by Frederick Ost in public collections in New Zealand. A considerable number of his works from the early 1930s to the early 1980s are, however, extant in private collections in England, New Zealand and Australia.

43 According to his close friends in New Zealand and his nephew in England he regarded New Zealand as his home, and, except for a period in Sydney from 1970-73, never considered living elsewhere.

44 J. G. Bläschke Verlag was based first in Darmstadt, before shifting to St Michael, Austria. Bläschke published four of Ost's books: Mein kleines Schwalben-Bach (1983), Die Aotearoa Tiki Botschaften, (1984), Zeitgenossen im zerbrochenen Spiegel (1985), and Vier Stimmen aus der Grossstadt (1983).
} 


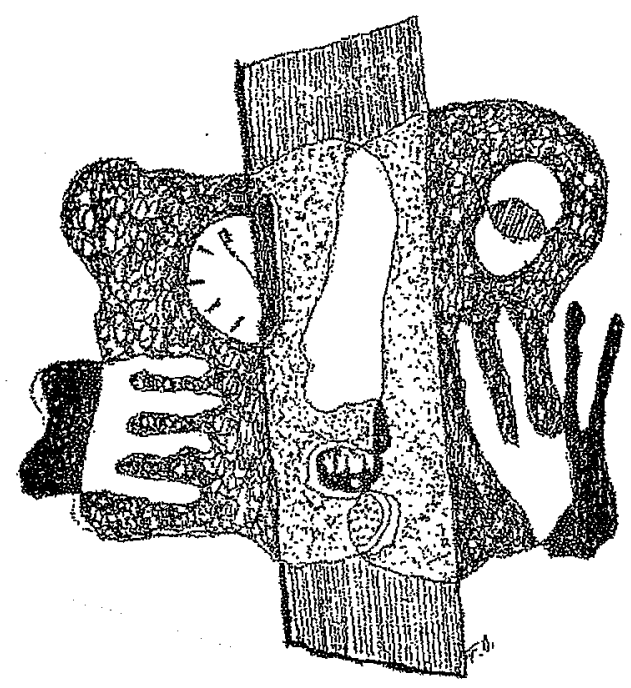

Frederick Ost, Zeitgenosse im zerbrochenen Spiegel (1985)

A younger German-Jewish refugee, Reinhard Bendix (1916-91), who was to become a leading sociologist and political scientist in the USA, and the author of From Berlin to Berkeley (1986), has written:"Our affinities are unsettled, and unsettling, personally, socially and politically. All of us stand at the intersection of many social groups - family, social class, occupation, ethnic or national affiliation"45, to which one could add literary or artistic groupings or sub-cultures. For those, like Ost and Wolfskehl, subject as refugees to inevitably profoundly unsettling experiences dislocations - their affinities in coming as strangers to new and different countries were likely to be much, much more unsettled than the native-born of those countries - a likelihood to which their art intensely testifies.

Acknowledgements:

Photograph of Frederick Ost (Private Collection, Wellington).

Frederick Ost, Tiki in Mirror, 1946, from Tikis: Impressions inBlack and White (Wellington, The Handcraft Press, 1946).

45 Bendix, Reinhard, Unsettled Affinities, New Brunswick, New Jersey 1993, p. xi. 
Frederick Ost, Still Life, 1945, pen \& ink on paper, (Private Collection, Wellington).

Frederick Ost, A Stranger Arrives, 1944, pen \& ink on paper, (Private Collection, Wellington).

Frederick Ost, untitled abstraction, 1932, pen \& ink on paper, (Private Collection, London).

Frederick Ost, frontispiece illustration, Zeitgenossen in zerbrochnen Spiegel (Sankt Michael, Blaschke, 1985). 